\title{
Professional Deformations of a Lawyer and Deformations of Legal Mind: Connection and Interaction. Experience of Modern Russia
}

\author{
Yana V. Gaivoronskaya ${ }^{1}$ \\ ${ }^{1}$ Law School, Northern Far-Eastern Federal University, Vladivostok, Russian Federation \\ Correspondence: Yana Gaivoronskaya, Law School, Far-Eastern Federal University, Vladivostok, 690009, \\ Vladivostok, Anisimova str, 66-40, Russia. Tel: 7-914-790-9213. E-mail: yannavlad@gmail.com
}

\author{
Received: April 26, 2013 Accepted: July 2, 2014 Online Published: August 20, 2014 \\ doi:10.5539/ass.v10n17p80 URL: http://dx.doi.org/10.5539/ass.v10n17p81
}

\begin{abstract}
In this article the author is observing possible professional deformations of the personality of a lawyer. Some professional deformations can make a person unsuitable for his work. The author proves that talking about lawyers' professional deformations we should mostly speak about deformations of their legal mind. But observing the problem of low-leveled legal mind from the other hand, we can say that such legal mind can prevent some types of professional deformations as well.
\end{abstract}

Keywords: lawyers, professional deformation, professional legal activity, deformations of legal mind, professional competence of a lawyer, law

\section{Introduction}

Nowadays a set of professional knowledge and skills (for example in jurisprudence, medicine, management, information technology, etc.) is not all a person needs to be successful in his career. Graduates of a modern university will act in the conditions of tough competition on the labor market; they must know how to "sell themselves", be well received by an employer and business partners, integrate into professional community, prove to be a promising employee. Graduates' experience of employment shows that excellent academic performance does not guarantee same level of success in practical professional activities. It often happens that former A-students holding honor diplomas encounter problems as they seek to get employed, eventually taking up entry-level positions, perform ministerial duties with low or average income. At the same time C-students who did not show any significant academic results make brilliant careers, start their own businesses and take up managerial positions. Apparently, social realization of a graduate does not depend exclusively on theoretical knowledge and practical skills they mastered as students. There are other factors that impact one's social realization. Among the disciplines that study these factors are psychology and acmeology of professional activities, psychology of professionalism, occupational psychology and legal psychology (as it pertains to lawyers).

We can discriminate two approaches to understanding professionalism - sociological and psychological. Authors of sociological school define an activity as professional to distinguish it from non-professional performance of similar work; this evokes such parameters of the activity as systemic performance, performing it on a paid-for basis, being specifically trained for performing this activity (Zhalinsky, 2008). From psychological perspective professionalism is a property of an activity, expertise, high efficiency in performing the activity. In this sense professional activity in performed by a professional as highly skilled expert in his / her field. Within the framework of this study we will utilize psychological approach since it focuses on personal traits and skills that help one succeed professionally. Contemporary psychology of professions views professionalism as a general property that characterizes the subject of labor. This property enables him / her to perform professional activities and achieve significant results in any field almost independently from type and specifics of the activity. Professionalism is not only new highest level of knowledge and one's total result in a certain field; it is a certain system that characterizes organization of one's mind, one's psyche (Derkach \& Zazykin, 2003).

Legal knowledge itself is not all a modern lawyer needs to practice law efficiently. Auspicious social realization requires communication skills, good command in modern methods of search and analysis of information, high level of self-organization and other skills. Under the current conditions professional competency of a lawyer is a complex of several professional competencies that help realize one another. Competency is quality of an 
employee's actions that ensure proper and efficient solutions for problem-plagued profession-related tasks, readiness to incur liability for one's actions. Each type of professional competence manifests in a set of separate competencies viewed as one's abilities to perform certain type of activities.

So, being a professional lawyer nowadays means to be able to perform successfully in any sphere. And to our regret, this often means that a person can "loose himself", loose his soul while building that thing that is usually called a 'successful career".

In this article we would like to observe legal mind as a main factor of professional adoptability of a lawyer. Legal mind consists of professional legal knowledge, person's attitude to law and his thoughts about law's role in the life of the society. Legal mind of a lawyer is created because of two main factors: first of all, special education and secondly, because of practicing him law.

Talking about lawyers' legal mind we can not forget about general acmeological invariants of professionalism:

a) power of personality (various volitional powers and ability to assume liability);

б) advanced anticipation (ability to predict accurately and reliably, forestall development of situations that arise in course of professional activities);

в) high level of self-regulation (ability to manage one's condition, high performance ability, resistance to stress, readiness to take urgent actions, ability to mobilize one's resources when it is necessary);

г) ability to make decisions (courage in making decisions, reliability of decisions made, their timeliness and accuracy, uniqueness and efficiency);

д) creativity (manifested not solely in high creative potential, but in ability to accomplish professional tasks efficiently through non-standard solutions);

e) being highly and adequately motivated to achieve.

So, we can easily notice that all pointed categories (concerning a lawyer) are built in the special powerful mind and a special type of legal mind first of all.

And a professional deformation is a negative modification of person's mind because of which he begins to fancy law inadequately. The notion "deformation" is used in jurisprudence to characterize negative changes of a person's mind that lead to illegal behavior or to negative attitude towards law itself (Voplenko, 2003).

Modern science formulates lots of types of deformations of the legal mind. There are two opposite extremes: legal idealism and legal nihilism. Legal idealism means that a person thinks that law is super phenomenon and is able to solve any problem if the laws are properly made. Legal nihilism is an opposite phenomenon, a person with such deformation doesn't believe in the possibilities of law and its values for the society and, as a result, he doesn't want to obey the laws. There are some different deformations. For example, legal infantilism - a person knows almost nothing about law but he is sure he knows everything. Or legal subjectivism - a person is correlating any law with his own profit and ideas, he just ignores the real meaning of legal concepts. The best example of such deformation is a situation when a person is insisting that he has rights but he forgets that he also has some responsibilities.

We are not going to characterize all possible deformations of legal mind in this article. There is no doubt that any deformation leads to disobeying the norms of the law, generates illegal behavior and corruption and, as a result, people stop believing in law and law enforcement authorities.

\section{Research Methodology}

In our article we will mostly use the method of scientific hypothesis. We will presume that deformation of legal mind of a lawyer is, firstly, the demonstration of his professional deformation and, secondly, a factor for creating other professional deformations. To prove our hypothesis we will use such special scientific methods as method of observation and logical analysis.

\section{Results and Discussion}

Professional deformation of personality means changing of mental structure and features of personality because of accomplishing professional tasks.

Every profession initiates the creation of professional deformation of a personality.

According to professional psycology, professional deformations usually develop in people, who use to constantly communicate with other people: doctors, teachers, service workers, people who serve in the structures of law 
enforcement-bodies etc. Jurisprudence is a «human-human» profession, so the problem of professional deformation is very actual for it.

According to E.F.Seer, professional deformations can be detected on four levels: (Zeer, 2005)

1. Common deformations, typical for such workers. These are specialties of behaviour, which can be watched on the most of long time working people. For example, for doctors the syndrome of «compassionate tiredness» is typical. It is expressed in emotional indifference to pationate's sufferings. Workers of law enforcement-bodies often consider everyone as a potential criminal. This is called «asocial perseption». Administrators often suffer because of the syndrome of "permissiveness», which is expressed in breaking the rules of professional and ethical norms' strong desire for manipulating his worker's professional lives.

2. Special professional deformations are being created during the specializations in profession. Every profession unites several specializations, and each has its own professional deformations. So, investigator acquires legal suspicion, an operative worker -aggressiveness, an advocate - professional resourcefulness, and a prosecutor accusation.

3. Typical professional deformations are caused by co-existence of individual-psycological specialties of a person (temper ability, character) and psycological structure of professional activities. For example, professionally oriented deformations (distortion of motivative activity, sceptical attitude towards new workers); deformations, based on talents: administrative, communicative, intellectual, etc. (complex of superiority, hypertrophied level of pretensions, overstated self-apprasial, psycological hermetizations, narcissism, etc).

4. Individualized deformations are caused by the individual personal speciallities of workers of diffrent professions. During the process of long-term accomplising professional activitiessome talents can be even developed. As a result of psycological unity of the personality and profession some features can be transformed into accentuations. For example, overresponsibility, superhonour, hyperactivity, labour fanatism, professional enthusiasm.

Professional deformations of lawyers are still not well explored. And existing analitic explorations usually concern only lawyers from law enforcement-bodies. There are some marked forms of professional deformations concerning such people: over suspicion; accusatory in communication with people; narrow professionalism; prejudice; lack of self-control; superhero-feeling; abusing power; stereotype acts during communication; indifference (Zeer, 2005).

There is another classification, according to which all deformations of the lawyer can be divided conditionally into the general and special. It is necessary to understand the negative psychological changes peculiar to any person irrespective of a sort of its employment at contact with the right as the general. Traditionally the jurisprudence carries to such deformations: legal infertility, negativism and legal idealism. What are peculiar mainly to the persons who are engaged in lawyer activity concern special deformations. To them it is possible to carry treachery of the client, corporation treachery, envy to colleagues, a self-interest, incompetence, passivity, neglect interests of the client, effect "the provincial lawyer", etc. (Melnichenko, 2007)

The reasons for professional deformations of the lawyers are various. Mostly they are objectively connected with specifics of legal profession. For example, talking about law enforcement activities we can pick out following causes of professional deformations. Firstly, constant communication with offenders and close connection to criminal world. Secondly, communication with people in conflict situations. Thirdly, the fact that lawenforcement-bodies are full of people, who are psychologically not ready for such activities (non-quality choice). Fourthly, constant being among people accomplishing the function of the order guardian. This function initiates psychological tension and requires self-control. Fifthly, constant physical and mental overload, which lead to impoverishment intellectual and cultural evolution of the worker. Sixthly, variety of the stress situations, which cause psychological irritation (Dimitrov, 2003). Probably, these reasons all in all we can spread on other types of lawyers too.

Deformations of legal mind influence the formation of the professional competence and implementation of legal activities. Moreover, deformations of sense of justice can lead to professional unsuitability. Let's see how it can happen.

The extreme form of deformation is (according to Russian textbooks) «anti-legal consciousness». It is expressed in wrong acts, which are done on purpose. Talking about lawyers in law enforcement-bodies and government, extreme level of professional deformation and professional impropriety will lead to committing official crimes and corruption behavior. 
Les's analyze the official statistics of the General Prosecurity of Russia. Anti-corruption activity nowadays is one of the basic directions of the legal politics of Russian government. According to this, corruption crimes are marked as a special group of crimes in the documents of the law enforcement-bodies. According to official documents, in 2012 there were registed 49513 corruption crimes. The number of coppuption crimes which were represented in the court is 21263 . The most part of it - $26 \%$ - were commited in the lawenforsement sprhere. For example, in the sphere of public health and social ensuring were committed $17.8 \%$ crimes, in the sprhere of education and science $-15 \%$, in the sphere of financial activity $6,2 \%$. In 2011 share of the corruption crimes in the sphere of lawenforsement-bodies is $34,1 \%$ (Note 1 ).

Analyzing statistics, we can see, that most part of corruption crimes in Russia is committed in Russia in the sphere of law enforcement-bodies. Such crimes include bribery, fraud, abusing official powers, excess of official powers, misappropriation and embezzlement, forgery. But people, who serve in this structure, are lawyers. As it was wisely said by one of my colleagues, professional deformations are largely influenced by surroundings and by the initial mentality of the human element in which it is noticed (Note 2). It means «I see how you are doing and I am trying to copy it». So, when a young lawyer comes somewhere to start his professional activities, he is really influenced by the behavior of his more experienced colleagues. And we can do nothing with this fact.

\section{Conclusion}

So, in our opinion, the cause of corruption in legal sphere is deformation legal mind. We have analyzed the reasons for professional deformations. But mentioned reasons, which influence all the workers, who take part in the similar kind of activity, differently affect on different people. One person can get significant and stable change of attitude towards whole world and this will change his personal features and behavior. As a result, he will get deformations, that will negatively influence his work and life and will cause the low quality of professional activities and communication in general. Another person will be able to prevent deformations and outside obstacles because of it's own principles, life position and values. To my mind, well formed professional features of a lawyer and existence of strong, not deformed legal mind are factors, which prevent evolution of professional deformations. Moral and ethical features are the basis of a personality, that can save its unity.

Deformations of legal mind can make a lawyer unable to do his work and to be useful for the society, because neglect for the respect of law (as a basis of professional deformation) can lead to the lack of professional knowledge and, as a result, to unappropriated behaviour. Respecting law , respecting profession and self-esteem - these terms must be unbreakable for any lawyer.

\section{References}

Derkach, A., \& Zazykin, V. (2003). Acmeology: Study guide / - Saint Petersburg (p. 227).

Dimitrov, A.V. (2003). Entrance in judicial psychology. Course of lections (p. 86).

Melnichenko, R. G. (2007). Samyj a heavy sin of the lawyer//the Lawyer. Retrieved from http://melnichenko.net/_p_name29en.html

Voplenko, N. N. (2000). Legal mind and legal culture (p. 25). Volgograd.

Zeer, E. F. (2005). Psychology of professions. Textbook for students (p. 321). Moscow.

Zeer, E. F. (2005). Psychology of professions. Textbook for students (pp. 240-241). Moscow.

Zhalinsky, A. E. (2008). Introduction into profession "Jurisprudence". In Professional activities of a lawyer. Textbook (pp. 56-61). Moscow: Prospect Publishing House.

\section{Notes}

Note 1. Doi: http://genproc.gov.ru/anticor/doks/document-81540/

Note 2. Doi: http://archive.org/stream/jstor-2763633/2763633_djvu.txt

\section{Copyrights}

Copyright for this article is retained by the author(s), with first publication rights granted to the journal.

This is an open-access article distributed under the terms and conditions of the Creative Commons Attribution license (http://creativecommons.org/licenses/by/3.0/). 